University of Nebraska - Lincoln

DigitalCommons@University of Nebraska - Lincoln

$1-19-2014$

\title{
Effectiveness of Rodenticides for Managing Invasive Roof Rats and Native Deer Mice in Orchards
}

Roger A. Baldwin

Niamh Quinn

David H. Davis

Richard M. Engeman

USDA-APHIS-Wildlife Services, s_r100@yahoo.com

Follow this and additional works at: https://digitalcommons.unl.edu/icwdm_usdanwrc

Part of the Life Sciences Commons

Baldwin, Roger A.; Quinn, Niamh; Davis, David H.; and Engeman, Richard M., "Effectiveness of Rodenticides for Managing Invasive Roof Rats and Native Deer Mice in Orchards" (2014). USDA National Wildlife Research Center - Staff Publications. 1433.

https://digitalcommons.unl.edu/icwdm_usdanwrc/1433

This Article is brought to you for free and open access by the U.S. Department of Agriculture: Animal and Plant Health Inspection Service at DigitalCommons@University of Nebraska - Lincoln. It has been accepted for inclusion in USDA National Wildlife Research Center - Staff Publications by an authorized administrator of DigitalCommons@University of Nebraska - Lincoln. 


\section{Effectiveness of rodenticides for managing invasive roof rats and native deer mice in orchards}

\section{Roger A. Baldwin, Niamh Quinn, David H. Davis \& Richard M. Engeman}

Environmental Science and Pollution Research

ISSN 0944-1344

Volume 21

Number 9

Environ Sci Pollut Res (2014)

21:5795-5802

DOI 10.1007/s11356-014-2525-4

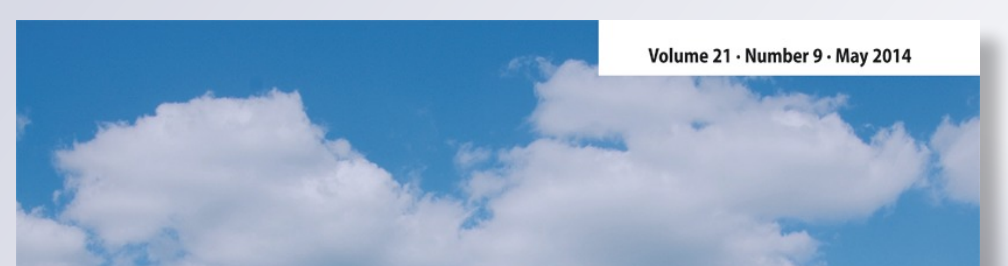

Environmental science and-pollution Research

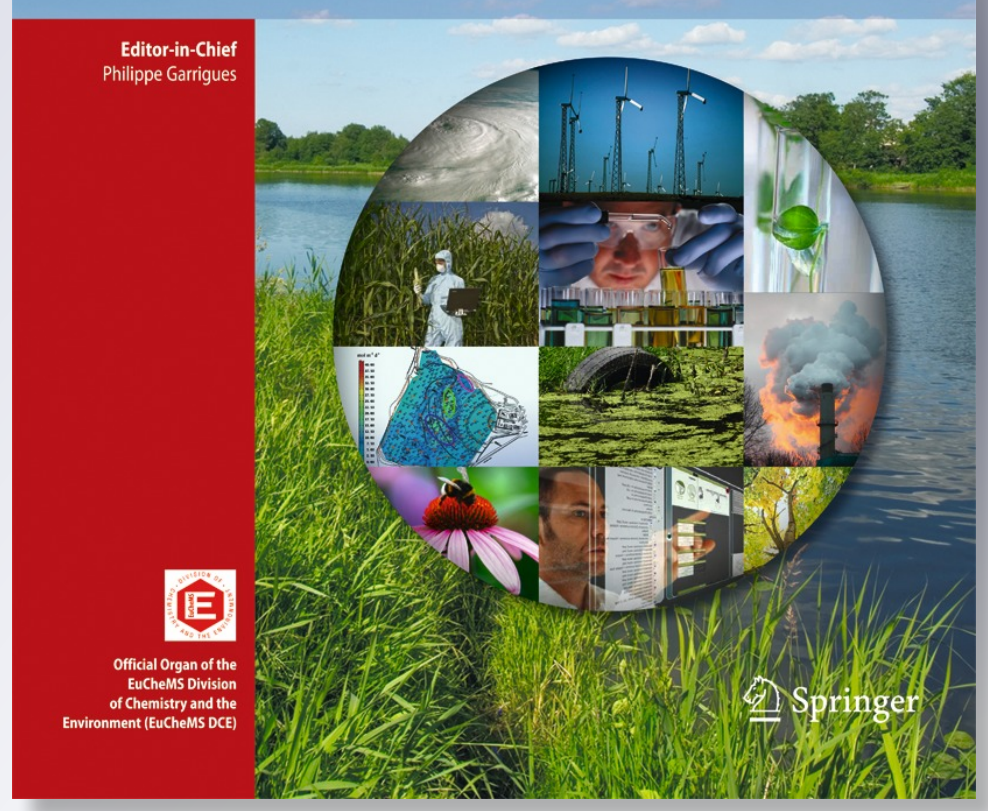

包 Springer 
Your article is protected by copyright and all rights are held exclusively by SpringerVerlag Berlin Heidelberg. This e-offprint is for personal use only and shall not be selfarchived in electronic repositories. If you wish to self-archive your article, please use the accepted manuscript version for posting on your own website. You may further deposit the accepted manuscript version in any repository, provided it is only made publicly available 12 months after official publication or later and provided acknowledgement is given to the original source of publication and a link is inserted to the published article on Springer's website. The link must be accompanied by the following text: "The final publication is available at link.springer.com". 


\title{
Effectiveness of rodenticides for managing invasive roof rats and native deer mice in orchards
}

\author{
Roger A. Baldwin • Niamh Quinn • David H. Davis • \\ Richard M. Engeman
}

Received: 15 October 2013 / Accepted: 6 January 2014 / Published online: 19 January 2014

(C) Springer-Verlag Berlin Heidelberg 2014

\begin{abstract}
Roof rats (Rattus rattus) and deer mice (Peromyscus maniculatus) are occasional pests of nut and tree fruit orchards throughout California and in many other parts of the USA and beyond. In general, the most practical and costeffective control method for rodents in many agricultural environments is the use of rodenticides (toxic baits), but little or no information exists on the efficacy of current rodenticides in controlling roof rats and deer mice in orchards. Therefore, our goals were to develop an index of rodent activity to monitor efficacy of rodenticides and to subsequently test the efficacy of three California Department of Food and Agriculture rodenticide baits $(0.005 \%$ chlorophacinone treated oats, $0.005 \%$ diphacinone treated oats, and $0.005 \%$ diphacinone wax block) to determine their utility for controlling roof rats and deer mice in agricultural orchards. We determined that a general index using the number of roof rat photos taken at a minimum of a 5-min interval was strongly correlated to the minimum number known estimate of roof rats; this approach was used to monitor roof rat and deer mouse populations preand post-treatment. Of the baits tested, the $0.005 \%$ diphacinone treated oats was most effective for both species; $0.005 \%$ chlorophacinone grain was completely ineffective
\end{abstract}

Responsible editor: Philippe Garrigues

R. A. Baldwin ( $\square)$

Department of Wildlife, Fish, and Conservation Biology,

University of California, One Shields Ave., Davis, CA 95695, USA

e-mail: rabaldwin@ucdavis.edu

N. Quinn · D. H. Davis

Kearney Agricultural Research and Extension Center,

University of California, 9240 South Riverbend Avenue, Parlier,

CA 93648, USA

R. M. Engeman

USDA/Wildlife Services, National Wildlife Research Center,

4101 LaPorte Avenue, Fort Collins, CO 80521, USA against roof rats. Our use of elevated bait stations proved effective at providing bait to target species and should substantially limit access to rodenticides by many non-target species.

Keywords Bait station · Chlorophacinone · Deer mouse · Diphacinone $\cdot$ Human-wildlife conflict $\cdot$ Peromyscus maniculatus $\cdot$ Rattus rattus $\cdot$ Roof rat

\section{Introduction}

Rats (Rattus spp.) are a common and very damaging invasive pest found throughout much of the world, with one projection of damage caused by rats in the USA estimated at $\$ 19$ billion annually (Pimentel et al. 2005). Although much of the damage they cause occurs in residential areas, they are also common agricultural pests. In particular, nut and tree fruit crops can incur substantial damage from rats when present. For example, roof rats (Rattus rattus) cause an estimated 5-10\% loss in developing macadamia nut crops in Hawaii each year (Tobin et al. 1997). Roof rats can also cause frequent damage to citrus crops (Worth 1950).

Deer mice (Peromyscus maniculatus) are another common pest in North American agriculture. Unlike roof rats, deer mice are native to many areas in North America. Damage from deer mice can be substantial, with estimates of $\$ 51$ per hectare reported in some almond orchards in Fresno County, CA (Pearson et al. 2000). In situations where this level of damage occurs, managing rodent populations is required to increase crop production and profits.

Applications of rodenticide baits are often the preferred technique used to control rat and mouse populations as they are relatively quick and inexpensive to apply and can be highly efficacious (Witmer et al. 1998). Many rodenticides have been developed to control rodent populations (e.g., 
brodifacoum, bromethalin, chlorophacinone, diphacinone, zinc phosphide; Gill 1992; Pitt et al. 2011), and several studies have assessed their ability to control roof rats and deer mice in natural areas (e.g., Donlan et al. 2003; Radvanyi 1980; Witmer et al. 2007a). However, we are aware of no peerreviewed studies that have tested the efficacy of rodenticides for roof rat control in nut or tree fruit crops, and few, if any, such studies have been conducted on deer mice. A thorough understanding of the efficacy of field-use rodenticides is needed to insure the development and implementation of effective management programs for these rodent species.

The California Department of Food and Agriculture (CDFA) has several long-standing registrations for controlling rodent pests on agricultural lands throughout the state. These products provide affordable rodent control and are heavily used by many of the state's residents (Newman et al. 2010). Field efficacy of these baits has been thoroughly tested for some rodents (e.g., California ground squirrel, Otospermophilus beecheyi; Salmon et al. 2007), but efficacy results are lacking for roof rats and deer mice. An initial laboratory study indicated that the CDFA $0.005 \%$ diphacinone grain bait was ineffective against roof rats (Whisson et al. 2004). However, field conditions often influence the efficacy of baits, sometimes resulting in greater efficacy than that observed in laboratory settings (Pitt et al. 2011). Therefore, field trials that reflect the actual conditions where baits are distributed should provide a more realistic test of these rodenticides. Such tests would be highly valuable to afflicted growers as they have no practical alternative for roof rat or deer mouse control in orchards, yet have no assurance that these rodenticides are effective in a field setting.

To test the efficacy of these rodenticides, we need an effective method to monitor roof rat and deer mouse activity pre- and post-treatment. Development of simple, quantitative indexing techniques is important for managing a variety of wildlife species. To be practical, such an index should be simple and easily applied in the field, while being sensitive to population changes. A general paradigm with good quantitative properties for indexing animal populations has been developed and applied to many species using many observation methods (e.g., European rabbit, Oryctolagus cuniculus [Latham et al. 2012] and wild pigs, Sus scrofa [Engeman et al. 2007; Bengsen et al. 2011]). In particular, this approach has served well for rodents (Engeman and Whisson 2006; Whisson et al. 2005). The basic requirements include placing observation stations throughout the area of interest, with observations made on consecutive days at each indexing occasion (e.g., before and after a treatment; Engeman 2005). The development of such an approach for roof rats and deer mice would fit this paradigm and would allow us to test the efficacy of selected rodenticides. Therefore, our specific goals were as follows: (1) develop an index of rodent activity and (2) test the efficacy of $0.005 \%$ chlorophacinone treated oats, $0.005 \%$ diphacinone treated oats, and $0.005 \%$ diphacinone wax block on roof rat and deer mouse populations in elevated bait stations designed to minimize non-target exposure.

\section{Materials and methods}

Indexing trials

We established five $180 \times 210$-m sampling plots to develop an index for monitoring roof rat populations in almond orchards. Four plots were established in western Fresno County, CA, while one plot was located in Yolo County, CA. We measured roof rat activity using remote-triggered cameras (hereafter, cameras) and chewing on non-toxic wax blocks. For our chewing index, we wrapped nontoxic wax bait blocks (Detex ${ }^{\circledR}$, Bell Laboratories, Inc., Madison, WI) on branches in almond trees using baling wire at $30-\mathrm{m}$ intervals following a $6 \times 5$ pattern with the outside rows $30 \mathrm{~m}$ from the edge of the plot (Fig. 1). Wax blocks were removed and weighed daily for three consecutive days to calculate the amount of block

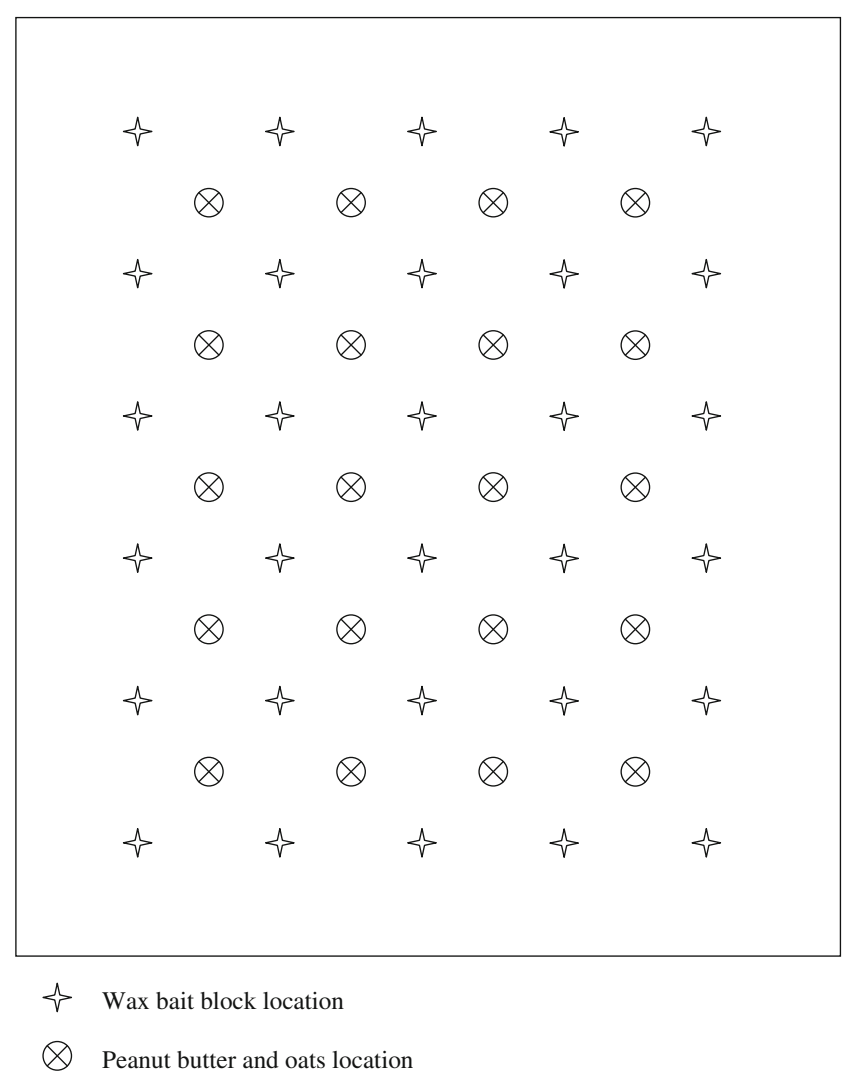

Fig. 1 Layout of indexing locations used to determine the relationship between the number of captured roof rats, and the number of photos of roof rats baited with (1) wax blocks and (2) peanut butter and oats. Peanut butter and oat locations were $45 \mathrm{~m}$ from the edge of the plot and were spaced $30 \mathrm{~m}$ from each other. Wax bait blocks were $30 \mathrm{~m}$ from the edge of the plot and were spaced $30 \mathrm{~m}$ from each other resulting in overall plot dimensions of $180 \times 210 \mathrm{~m}$ 
removed by roof rats. However, chewing on wax blocks was minimal ( $0.09 \mathrm{~g}$ [SE=0.04] per block), so we did not pursue the use of a chewing index further. We also placed cameras (Scoutguard ${ }^{\circledR}$ SG550, HCO Outdoor Products, Norcross, GA) on these blocks during the same time period to provide an alternative method for assessing activity. Cameras were set with a 30-s minimum delay between photos. Date and time were recorded for all photos.

We also assessed visitation to peanut butter and oats using cameras. The peanut butter and oat bait consisted of approximately $15 \mathrm{~cm}^{3}$ of a $50: 50$ ratio of creamy peanut butter (Great Value ${ }^{\circledR}$ brand, Walmart, Bentonville, AR) and rolled and crimped oats (Grain Millers, Eugene, OR). These camera sites followed a $5 \times 4$ pattern with cameras spaced at $30-\mathrm{m}$ intervals; the outside rows were $45 \mathrm{~m}$ from the edge of the plot (Fig. 1). Camera protocols were the same as reported for the wax blocks. Wax block and peanut butter and oats camera sites were operated at the same time for each sampling plot.

Upon completion of the 3-day index trials, we initiated live trapping using $13 \times 13 \times 46 \mathrm{~cm}$ Tomahawk live traps (Tomahawk Live Trap, Hazelhurst, WI) to determine a minimum number known estimate. Traps were secured to tree branches using baling wire or bungee cords and were baited with peanut butter and oats. Traps were checked daily for four consecutive days for captures. Upon capture, roof rats were tagged with No. 3 Monel ear tags (National Band and Tag Co., Newport, KY) to allow for individual identification, and weight and gender were recorded. Recaptured individuals were identified from their ear tags and weighed. All initial captures and recaptures were released at the trap site, with all camera and trapping operations occurring between 5 October and 30 November 2010.

From the above design, we had multiple observation types that could potentially be used for calculating an index. Indices based on different measurements are inherently different indices and not comparable (Engeman 2005). Thus, part of our task was to identify which observation type, when used in index calculations, best related to population levels. As already stated, we had intended to consider the amount lost to chewing on the placebo bait blocks as a measure to consider for developing an index. Although measures of chewing have been successfully used to develop indices for a variety of rodents (e.g., Engeman and Whisson 2006; Whisson et al. 2005), chewing did not provide an adequate measure for our application. However, roof rats were still attracted to the bait blocks even though their chewing was inconsequential, which allowed the bait blocks to be incorporated into camera indices.

We had a variety of considerations for photographic measures to use in indexing calculations. First, we had two attractants, bait blocks and peanut butter with oats. We also had to consider how we defined the number of intrusions into the camera view. Often the same animal can cause repeated triggers of the camera. We considered three measures of activity at each camera. The first was the total number of rat intrusions (images) per 24-h period. For example, a value of 1.0 indicates that, on average, we observed one photo per station per 24-h period. To reduce the effect of an animal triggering the camera repeatedly during a single visit, the second measure was the total number of intrusions separated by at least 5 min during a 24-h period. The final measure was a binary yes-no observation of whether a roof rat had visited each camera station during a 24-h period. Thus, we had six combinations from using two attractants and three measures of visitation to the camera stations to evaluate as to how to best construct an index. Values from the six different index methods for each block were subjected to a correlation analysis to determine which of the six methods best tracked the minimum number of known roof rats across plots.

It should be pointed out that we did not test this index against deer mouse captures as we originally did not intend to test these products on deer mice. However, we observed a relatively large population of deer mice in most fields. This abundant activity, combined with the fact that deer mice are known pests of many orchard crops (e.g., almonds; Pearson et al. 2000), encouraged us to test these same rodenticide baits on deer mice as well as roof rats. Given the large number of studies validating the use of a general index to monitor population changes (e.g., Bengsen et al. 2011; Engeman and Whisson 2006; Latham et al. 2012), we have no reason to believe that the same index of activity would not effectively represent changes in deer mouse populations pre- and posttreatment.

\section{Baiting trials}

We used a randomized complete block design to test the efficacy of $0.005 \%$ diphacinone oats (CDFA, Sacramento, CA), $0.005 \%$ diphacinone wax block (CDFA, Sacramento, CA), and $0.005 \%$ chlorophacinone oats (CDFA, Sacramento, CA) across three almond orchards in western Fresno County, CA, from 7 December 2010 through 22 February 2011, and one site from 22 December 2011 through 22 January 2012. Four $180 \times 210-\mathrm{m}$ treatment plots were established in each orchard with all three rodenticide baits and a control randomly assigned to each orchard.

\section{Indexing protocol}

Prior to bait application, we indexed roof rat and deer mouse populations in each treatment and control plot using remotetriggered cameras focused on nontoxic wax blocks. These camera sites followed a $5 \times 4$ pattern with cameras spaced at $30-\mathrm{m}$ intervals; the outside rows were $45 \mathrm{~m}$ from the edge of the plot (Fig. 1). Cameras were operated for $\sim 72 \mathrm{~h}$ and were set with a 5-min minimum delay, as this time frame strongly correlated to minimum number known estimates of roof rats in 
sampling plots. Date and time were recorded for all photos allowing us to use the number of photos taken to develop an index of roof rat and deer mouse activity before treatment. Index values were calculated for both species separately according to the formulae in Engeman (2005). This process was repeated immediately following the completion of baiting trials to allow us to determine the efficacy of the three rodenticides.

\section{Rodenticide baiting trials}

We used tubular bait stations manufactured specifically for Orange County (CA) Vector Control. They consisted of green high-density polyethylene plastic tubes (Industrial Plastic Supply, Inc., Anaheim, CA) that were $33 \mathrm{~cm}$ in length and $10.8 \mathrm{~cm}$ in diameter (Fig. 2). Steel end caps (AZ Manufacturing, Costa Mesa, CA) were placed on both ends of the tubes with a $4.8-\mathrm{cm}$ opening in the end caps that allowed the roof rats and deer mice to enter the station. We attached 30 tubular bait stations to almond tree branches in each treatment plot following a $6 \times 5$ pattern with the outside rows $30 \mathrm{~m}$ from the edge of the plot (Fig. 1). At each site, treatment plots were located adjacent to each other. The distances between the edge of treatment plots and bait stations (at least $30 \mathrm{~m}$ from edge of plot) and monitoring stations (at least $45 \mathrm{~m}$ from edge of plot) allowed us to assume essentially no impact of adjacent treatment plots on each other given a home-range size of $<0.5$ ha for roof rats (Recht 1988) and 0.1 ha for deer mice (Timm and Howard 1994).

The bait stations were placed in the trees during the indexing period to allow the roof rats and deer mice to acclimate to their presence before bait was supplied. We then loaded the bait stations with their respective rodenticides the day following the completion of the indexing period and initially checked bait levels daily to ensure a constant supply. After a few days, we only checked the stations approximately every 3 days, as sufficient bait was always present during this time frame. We added additional bait when remaining bait levels got low or when bait became wet from rainfall or fog. The bait stations were operated for $\sim 4$ weeks to allow sufficient time for acclimatization to the bait stations, as well as time for the rodents to find the bait and the anticoagulants to act. All aspects of this study were approved by the University of California, Davis' Institutional Animal Care and Use Committee (protocol no. 15743).

Statistical analysis

A measure of efficacy showing a $\geq 70 \%$ reduction in the target population following treatment is required for US EPA registration of rodenticides (Fagerstone et al. 1981). Thus, we used the $70 \%$ reduction as a minimum threshold for success for assessing each rodenticide treatment. We used one-sample Wilcoxon signed rank tests to determine if our observed post-treatment efficacy values for roof rats and deer mice differed from $70 \%$ (Conover 1999).

\section{Results}

Indexing trials

All photographic measures using wax blocks as an attractant had a superior correlation with the minimum number of known roof rats when compared to all of the measures using peanut butter and oats as an attractant (Table 1). Reducing the
Fig. 2 Sketch showing dimensions of bait station used for delivering anticoagulant baits to roof rats and deer mice in orchards in western Fresno County, CA

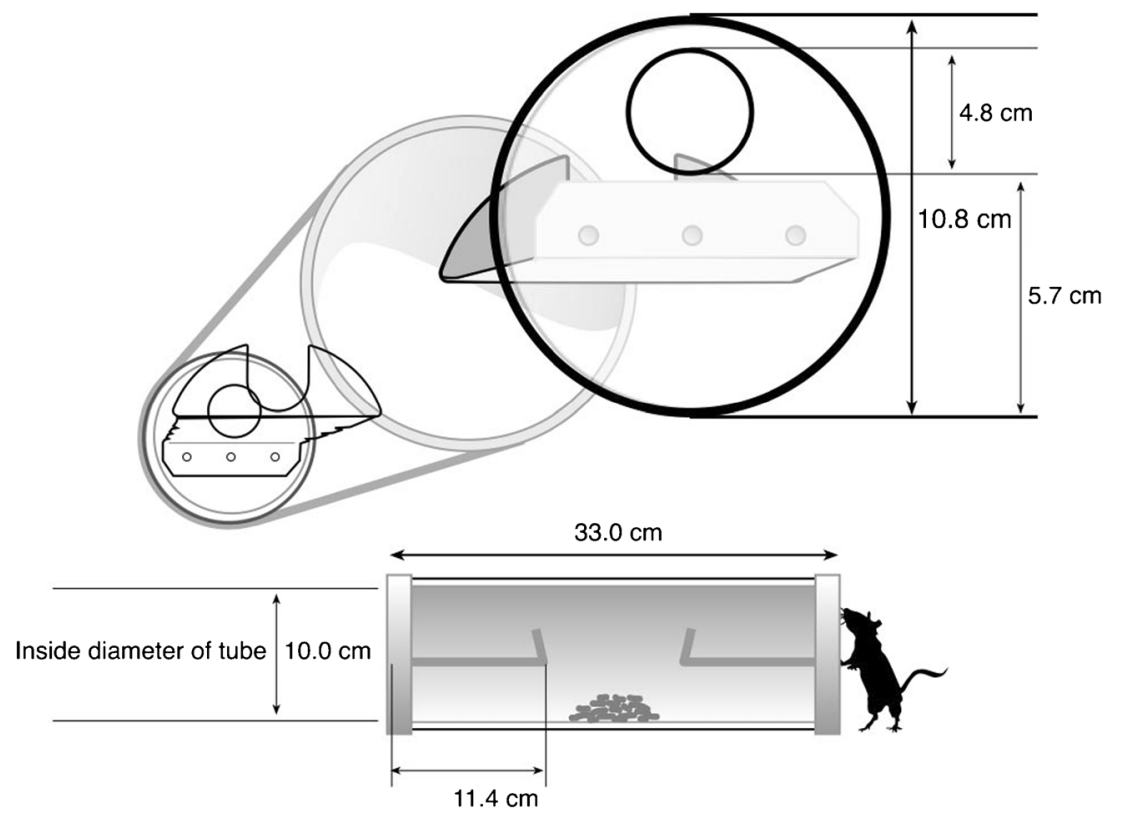


Table 1 The correlation $(r)$ and associated $P$ values comparing the minimum number of known roof rats at each site to three photographic measures calculated at each site; two attractants were tested across five sites in the San Joaquin Valley, CA, during autumn 2010

\begin{tabular}{lll}
\hline Attractant & Photographic measure $^{\mathrm{a}}$ & Correlation $_{(P \text { value })}$ \\
\hline Wax block & All images & $0.92(0.029)$ \\
& 5-min lag & $0.96(0.008)$ \\
& Binary & $0.81(0.100)$ \\
Peanut butter & All images & $0.71(0.180)$ \\
& 5-min lag & $0.67(0.220)$ \\
& Binary & $0.77(0.120)$ \\
\hline
\end{tabular}

${ }^{\text {a }}$ All images $=$ the total number of photos taken at a site, $5-\min$ lag $=$ the number of photos taken that are separated by a minimum of $5 \mathrm{~min}$, binary $=$ presence or absence of a roof rat at a camera station

number of photographic images to a binary measure was a clearly inferior approach and has been found in many studies to reduce sensitivity of an index to population changes (see Engeman 2005 for a discussion). The wax block attractant with a minimum 5-min lag between images had a very high correlation with the minimum known number of roof rats (Table 1) and was deemed the best indexing approach to use for evaluating the efficacy of rodenticide baits.

\section{Baiting trials}

We observed a $>70 \%$ reduction in roof rat activity at sites treated with diphacinone grain $(\bar{x}$ efficacy $=90 \% ; Z=-1.6, P=$ 0.05; Table 2) and, to a lesser extent, diphacinone wax blocks $(\bar{x}$ efficacy $=83 \% ; Z=-1.3, P=0.10)$. We observed an overall increase in activity at sites treated with chlorophacinone grain $(\bar{x}$ efficacy $=-170 \% ; Z=1.6, P=0.95)$. We also were not able to statistically detect a reduction at control sites $(\bar{x}$ efficacy $=$ $34 \% ; Z=1.6, P=0.95$; Table 2), indicating reductions in treatment plots were the result of applied rodenticides.

As with roof rats, we also observed a $>70 \%$ drop in deer mouse activity post-treatment for diphacinone grain $(\bar{x}$ efficacy $=99 \% ; Z=-1.6, P=0.05$; Table 3 ). We did not observe a statistically detectable reduction in activity at diphacinone wax block ( $\bar{x}$ efficacy $=63 \% ; Z=-0.2, P=0.43)$ or chlorophacinone grain $(\bar{x}$ efficacy $=67 \% ; Z=0.3, P=0.61)$ treatment plots. However, activity was quite low and occasionally nonexistent in some of the plots, thereby lowering our ability to detect differences (Table 3 ). Results from control plots $(\bar{x}$ efficacy $=16 \% ; Z=1.9, P=0.97$; Table 3$)$ did not statistically detect reductions in deer mouse activity indicating reductions in treated plots were likely due to treatment effects.

\section{Discussion}

Effective management of roof rats and deer mice relies largely on rodenticide baits (Witmer et al. 1998), yet there is a paucity of data on the efficacy of these materials in nut and tree fruit commodities. Of the three rodenticide baits tested in this study, the $0.005 \%$ diphacinone grain bait was clearly the most effective option for both roof rats and deer mice $(\bar{x}$ efficacy $=$ 90 and $99 \%$, respectively). The diphacinone wax block was also an effective control option for roof rats $(\bar{x}$ efficacy $=$ $83 \%$ ). Results from other studies on diphacinone have been highly varied. For island eradication of roof rats, pelleted diphacinone baits have been highly effective (e.g., Donlan et al. 2003; Witmer et al. 2007a). However, laboratory studies of roof rats provided with pelleted diphacinone baits have been less successful (Pitt et al. 2011), and the same CDFA diphacinone grain bait did not meet the $70 \%$ efficacy threshold in a previous lab study (Whisson et al. 2004). Pitt et al. (2011) point out that it can be difficult to predict if a rodenticide bait is going to be effective in a field study based on results from studies conducted in different field or laboratory settings, as many factors influence the attractiveness of a bait including the availability of alternative food sources, the method for which the bait was applied, etc. Some combination of these factors likely influenced the success we observed in this study. We tested the CDFA baits during winter in an almond orchard when alternative food sources were scarce. Additionally, the bait was housed in bait stations which

four sites (S1-S4) in western Fresno County, CA, from December 2010 February 2011 (S1-S3) and December 2011-February 2012 (S4)
Table 2 Roof rat pre- and post-treatment index values for three rodenticides (diphacinone block, diphacinone grain, and chlorophacinone grain) and a control, as well as their individual and mean efficacy values across

\begin{tabular}{|c|c|c|c|c|c|c|c|c|c|c|c|c|c|c|c|c|}
\hline & \multicolumn{4}{|c|}{ Control } & \multicolumn{4}{|c|}{ Diphacinone block } & \multicolumn{4}{|c|}{ Diphacinone grain } & \multicolumn{4}{|c|}{ Chlorophacinone grain } \\
\hline & $\mathrm{S} 1$ & S2 & S3 & S4 & S1 & S2 & S3 & S4 & $\mathrm{S} 1$ & S2 & S3 & S4 & $\mathrm{S} 1$ & S2 & S3 & S4 \\
\hline Pre-treatment & 2.30 & 0.05 & 0.08 & 0.63 & 0.70 & 1.37 & 0.78 & 0.05 & 3.87 & 0.38 & 0.03 & 0.28 & 0.78 & 0.02 & 0.67 & 0.23 \\
\hline Post-treatment & 0.48 & 0.03 & 0.05 & 0.73 & 0.05 & 0.28 & 0.02 & 0.02 & 0.17 & 0.05 & 0.00 & 0.05 & 0.20 & 0.07 & 0.30 & 1.43 \\
\hline Efficacy (\%) & 79 & 34 & 40 & -16 & 93 & 79 & 98 & 66 & 96 & 87 & 100 & 81 & 74 & -294 & 55 & -515 \\
\hline Mean efficacy (\%) & 34 & & & & $83 *$ & & & & $90^{* *}$ & & & & -170 & & & \\
\hline
\end{tabular}

$* P=0.10$, mean efficacy values were different than a $70 \%$ efficacy threshold; $* * P=0.05$, mean efficacy values were different than a $70 \%$ efficacy threshold 
Table 3 Deer mouse pre- and post-treatment index values for three rodenticides (diphacinone block, diphacinone grain, and chlorophacinone grain) and a control, as well as their individual and mean efficacy values across 4 sites (S1-S4) in western Fresno County, CA, from December 2010-February 2011 (S1-S3) and December 2011-February 2012 (S4)

\begin{tabular}{|c|c|c|c|c|c|c|c|c|c|c|c|c|c|c|c|c|}
\hline & \multicolumn{4}{|c|}{ Control } & \multicolumn{4}{|c|}{ Diphacinone block } & \multicolumn{4}{|c|}{ Diphacinone grain } & \multicolumn{4}{|c|}{ Chlorophacinone grain } \\
\hline & $\mathrm{S} 1$ & $\mathrm{~S} 2$ & $\mathrm{~S} 3$ & S4 & $\mathrm{S} 1$ & S2 & S3 & S4 & $\mathrm{S} 1$ & $\mathrm{~S} 2$ & $\mathrm{~S} 3$ & S4 & S1 & S2 & S3 & S4 \\
\hline Pre-treatment & 0.25 & 0.00 & 0.05 & 0.02 & 1.08 & 0.17 & 0.02 & 0.08 & 1.20 & 0.07 & 0.08 & 0.10 & 0.58 & 0.03 & 0.00 & 0.32 \\
\hline Post-treatment & 0.22 & 0.00 & 0.03 & 0.02 & 0.07 & 0.03 & 0.02 & 0.02 & 0.03 & 0.00 & 0.00 & 0.00 & 0.00 & 0.03 & 0.00 & 0.00 \\
\hline Efficacy (\%) & 13 & & 34 & 0 & 94 & 80 & 0 & 80 & 97 & 100 & 100 & 100 & 100 & 0 & & 100 \\
\hline Mean efficacy (\%) & 16 & & & & 63 & & & & $99 *$ & & & & 67 & & & \\
\hline
\end{tabular}

$* P=0.05$, mean efficacy values were different than a $70 \%$ efficacy threshold

provided a secure, abundant food source. As such, the tested baits should have been a highly preferred food source, and certainly that appeared to be the case in our study given the high efficacy of the diphacinone grain for both rodent species.

Not surprisingly, the diphacinone wax block did not perform as well as the loose grain bait in our study, as grain baits typically perform better than wax blocks (Timm 1994). However, wax blocks have the advantage of holding up better in damp conditions. Additionally, there is generally less concern about nontarget exposure from wax blocks when securely housed in bait stations, as spillage is less likely to occur with block baits. That being said, we observed very few instances of spillage of grain using the reported bait station design. This design provided a substantial internal lip that greatly reduced the possibility of the rodent kicking out grain onto the ground (Fig. 2). In the few instances when spillage was observed, it was never more than a few kernels of grain. Likewise, the bait station typically minimized the soaking of bait from rainfall. We did still observe wet grain during moderate to heavy rainfall which required the replacement of bait. However, wax blocks typically were sufficiently soaked from these same rain events to require replacement as well. As such, there seems to be little advantage to using the wax blocks instead of the grain baits.

The results for the diphacinone wax block and chlorophacinone grain were less clear for deer mice, with mean efficacy levels below the $70 \%$ threshold for both baits. However, the lower efficacy of these baits for deer mice was largely driven by one treatment plot for each bait that had two or less visits by period. All other treatment plots exhibited $\geq 80 \%$ efficacy (Table 3 ). Therefore, even though we cannot currently recommend the use of diphacinone treated wax blocks or chlorophacinone grain for deer mouse control in orchards, it appears likely that additional trials at sites with a greater density of deer mice could indicate that they are efficacious control options as well.

Surprisingly, the chlorophacinone grain bait provided little evidence of effectiveness for roof rats; chlorophacinone has proven very effective in other studies (e.g., Pitt et al. 2011; Whisson et al. 2004). Reasons for the observed low efficacy are unclear. It is possible that there could have been a problem during the mixing process that resulted in a lower level of active ingredient in the bait. However, the same batch of bait was used for all plots, and the bait was highly effective in the two plots with moderate deer mouse activity (Table 3 ). Alternatively, there may have been a different additive in the mixture that may have altered the palatability of the bait for roof rats, although most bait additives have little impact on palatability to rats (Salmon and Dochtermann 2006). Regardless of the cause, our findings indicate that the CDFA $0.005 \%$ chlorophacinone bait was ineffective against roof rats; the diphacinone alternative should be used in its place.

When using bait stations, it is always important to consider where to place these stations, as well as the spacing between bait stations. For our study, we used a 30-m distance between bait stations to provide a balance between sufficient access to bait to maximize efficacy and the cost effectiveness of implementing such a baiting program. Assuming homerange sizes ranging from 0.2 to 0.5 ha (Recht 1988), this would ensure access to several bait stations per individual roof rat. Deer mouse home ranges are typically $>0.1$ ha (Timm and Howard 1994). Assuming this size, individual deer mice would have access to at least one bait station within their home range. This spacing appeared to work quite well for both roof rats and deer mice given the high efficacy observed with some of the baits. Whisson et al. (2004) effectively used 50 -m spacing for a similar baiting program for roof rats in a mixed riparian forest in California. We did not test this greater spacing as we wanted to ensure deer mouse access to at least one bait station. However, if roof rats are the only species of concern, it seems likely that 50-m spacing would be effective in orchard crops as well.

For placement, bait stations can be located on the ground or elevated depending on the species being managed. Previous studies on roof rats have found that elevated baits are typically more effective than bait placed at ground level (e.g., Campbell et al. 1998), while bait is typically broadcast on the ground for deer mouse control (e.g., Witmer et al. 2007b). As such, we were not sure how deer mice would respond to elevated bait stations. Fortunately, the efficacy observed from the use of 
elevated bait stations was quite high for both species. In fact, we observed numerous deer mice and some roof rats nesting in the bait stations. Placing bait stations in trees limits access to other species of concern (e.g., Giant kangaroo rat, Dipodomys ingens), thereby providing a safe and effective method to mitigate nontarget exposure. This is an important consideration whenever planning a rodenticide application program for rodent control.

A field test of these rodenticides would not be possible without an effective method to monitor rodent activity within the treatment plots. We considered multiple observation and measurement methods configured so the observations could be used in a general indexing paradigm (Engeman 2005). Each combination of observation method (chewing on wax blocks, camera observations over wax blocks, camera observations over peanut butter and oats) and measurement method (missing mass from wax blocks, three photographic measures of activity) represented a different index approach even though calculation methods remained the same. It is a rare circumstance to be able to test indexing methods on populations of known abundance (Engeman 2005). While generally impractical as an indexing tool for control programs, the number known to be alive performs well for tracking population levels (e.g., better than mark-recapture methods) in a research context (Hopkins and Kennedy 2004; McKelvey and Pearson 2001) and served well for our index method selection. Even though we identified deer mice as another potentially damaging species subsequent to roof rat index development, camera observations are fortunately a method that permits detections and index calculations of multiple species simultaneously (Engeman 2005). Therefore, we were able to apply the general indexing approach to deer mice as well.

Acknowledgments We would like to thank numerous landowners for providing access to their property for this study and to H. Jantz and D. Stetson for valuable field assistance. We also thank G. Creekmur and S. Neblett for assistance in selecting an appropriate bait station design and $\mathrm{F}$. Rinder and R. Lantsberger for thoughtful discussions on this project. This project was funded by the Vertebrate Pest Control Research Advisory Committee of the California Department of Food and Agriculture.

\section{References}

Bengsen AJ, Leung LK-P, Lapidge SJ, Gordon IJ (2011) Using a general index approach to analyze camera-trap abundance indices. J Wildl Manag 75:1222-1227

Campbell EW III, Koehler AE, Sugihara RT, Tobin ME (1998) The development of an integrated pest management plan for roof rats in Hawaiian macadamia orchards. In: Baker RO, Crabb AC (eds) Proceedings of the 18th Vertebrate Pest Conference. University of California, Davis, pp 171-175

Conover WJ (1999) Practical nonparametric statistics. Wiley, New York
Donlan CJ, Howald GR, Tershy BR, Croll DA (2003) Evaluating alternative rodenticides for island conservation: roof rat eradication from the San Jorge Islands, Mexico. Biol Conserv 114:29-34

Engeman R (2005) Indexing principles and a widely applicable paradigm for indexing animal populations. Wildl Res 32:203-210

Engeman R, Whisson D (2006) Using a general indexing paradigm to monitor rodent populations. Intern Biodeterior Biodegrad 58:2-8

Engeman RM, Stevens A, Allen J, Dunlap J, Daniel M, Teague D, Constantin B (2007) Feral swine management for conservation of an imperiled wetland habitat: Florida's vanishing seepage slopes. Biol Conserv 134:440-446

Fagerstone K, Matschke G, Elias D (1981) Radiotelemetry to evaluate effectiveness of a new fumigant cartridge for controlling ground squirrels. Proceedings of the 3rd International Conference on Wildlife Biotelemetry. Laramie, Wyoming, pp 20-25

Gill JE (1992) A review of the results from laboratory tests of some rodenticides against eight rodent species. In: Borrecco JE, Marsh RE (eds) Proceedings of the 15th Vertebrate Pest Conference. University of California, Davis, pp 182-191

Hopkins HL, Kennedy ML (2004) An assessment of indices of relative and absolute abundance for monitoring populations of small mammals. Wildl Soc Bull 32:1289-1296

Latham ADM, Nugent G, Warburton B (2012) Evaluation of camera traps for monitoring European rabbits before and after control operations in Otago, New Zealand. Wildl Res 39:621-628

McKelvey KS, Pearson DE (2001) Population estimation with sparse data: the role of estimators versus indices revisited. Can J Zool 79: 1754-1765

Newman P, Hornbaker V, Salmon TP (2010) Vertebrate Pest Control Research Advisory Committee (VPCRAC): California's approach to supporting vertebrate pest control. In: Timm RM, Fagerstone KA (eds) Proceedings of the 24th Vertebrate Pest Conference. University of California, Davis, pp 353-355

Pearson AB, Gorenzel WP, Salmon TP (2000) Lesser-known vertebrate pests of almonds in California. In: Salmon TP, Crabb AC (eds) Proceedings of the 19th Vertebrate Pest Conference. University of California, Davis, pp 365-376

Pimentel D, Zuniga R, Morrison D (2005) Update on the environmental and economic costs associated with alien-invasive species in the United States. Ecol Econ 52:273-288

Pitt WC, Driscoll LC, Sugihara RT (2011) Efficacy of rodenticide baits for the control of three invasive rodent species in Hawaii. Arch Environ Con Tox 60:533-542

Radvanyi A (1980) Control of small mammal damage in the Alberta oil sands reclamation and afforestation program. Forest Sci 26:687-702

Recht MA (1988) The biology of domestic rats: telemetry yields insights for pest control. In: Crabb AC, Marsh RE (eds) Proceedings of the $13^{\text {th }}$ Vertebrate Pest Conference. University of California, Davis, pp 98-100

Salmon TP, Dochtermann NA (2006) Rodenticide grain bait ingredient acceptance by Norway rats (Rattus norvegicus), California ground squirrels (Spermophilus beecheyi) and pocket gophers (Thomomys bottae). Pest Manag Sci 62:678-683

Salmon TP, Whisson DA, Berentsen AR, Gorenzel WP (2007) Comparison of $0.005 \%$ and $0.01 \%$ diphacinone and chlorophacinone baits for controlling California ground squirrels (Spermophilus beecheyi). Wildl Res 34:14-18

Timm RM (1994) Norway rats. In: Hygnstrom SE, Timm RM, Larson GE (eds) Prevention and control of wildlife damage. University of Nebraska Cooperative Extension, U.S. Department of Agriculture, and Great Plains Agricultural Council, Washington, D.C, pp B105B120

Timm RM, Howard WE (1994) White-footed and deer mice. In: Hygnstrom SE, Timm RM, Larson GE (eds) Prevention and control of wildlife damage. University of Nebraska Cooperative Extension, U.S. Department of Agriculture, and Great Plains Agricultural Council, Washington, D.C, pp B47-B51 
Tobin ME, Koehler AE, Sugihara RT (1997) Effects of simulated rat damage on yields of macadamia trees. Crop Prot 16:203-208

Whisson DA, Quinn JH, Collins K, Engilis A Jr (2004) Developing a management strategy to reduce roof rat, Rattus rattus, impacts on open-cup nesting songbirds in California riparian forests. In: Timm RM, Gorenzel WP (eds) Proceedings of the 21st Vertebrate Pest Conference. University of California, Davis, pp 8-12

Whisson DA, Engeman RM, Collins K (2005) Developing relative abundance techniques (RATs) for monitoring rodent populations. Wildl Res 32:239-244

Witmer GW, Campbell EW III, Boyd F (1998) Rat management for endangered species protection in the U.S. Virgin Islands.
In: Baker RO, Crabb AC (eds) Proceedings of the 18th Vertebrate Pest Conference. University of California, Davis, pp 281-286

Witmer GW, Boyd F, Hillis-Starr Z (2007a) The successful eradication of introduced roof rats (Rattus rattus) from Buck Island using diphacinone, followed by an irruption of house mice (Mus musculus). Wildl Res 34:108-115

Witmer G, Sayler R, Huggins D, Capelli J (2007b) Ecology and management of rodents in no-till agriculture in Washington, USA. Integr Zool 2:154-164

Worth CB (1950) Field and laboratory observations on roof rats, Rattus rattus (Linnaeus), in Florida. J Mamm 31:293-304 